\title{
Spatial-temporal dynamics of N-cycle functional genes in a temperate Atlantic estuary (Douro, Portugal)
}

\author{
P. Salgado ${ }^{1,2, *}$, A. Machado ${ }^{1,2}$, A. A. Bordalo ${ }^{1,2}$ \\ ${ }^{1}$ Institute of Biomedical Sciences (ICBAS), University of Porto, R. Jorge de Viterbo Ferreira 228, 4050-313 Porto, Portugal \\ ${ }^{2}$ Interdisciplinary Centre of Marine and Environmental Research (CIIMAR/CIMAR), University of Porto, \\ Terminal de Cruzeiros do Porto de Leixões, Av. General Norton de Matos s/n, 4450-208 Matosinhos, Portugal
}

\begin{abstract}
Understanding the spatial and seasonal dynamics of nitrogen (N)-cycle microbial communities is pivotal for the knowledge of $\mathrm{N}$ biogeochemistry. The present study addressed the spatial-temporal variability of nitrification (bacterial and archaeal amoA) and denitrification (nirS, nirK, and nosZI) key genes, as well as of non-denitrifying nitrous oxide $\left(\mathrm{N}_{2} \mathrm{O}\right)$ reducers (nosZII), coupled with key environmental variables, in an estuarine ecosystem (Douro, NW Portugal). Samples were collected on a monthly basis over 1 yr, key physical-chemical parameters were measured, and specific functional gene abundances were assayed. The results revealed a clear seasonality for nirS, nosZII, and bacterial and archaeal amoA abundance, with an increase during the winter/spring seasons. This period was especially characterized by high levels of dissolved oxygen, low temperature, low salinity, and increased turbidity. Indeed, turbidity emerged as the key factor controlling the distribution of nirS, nosZII bacterial, and archaeal amoA abundance. In contrast, the abundance of nosZI increased during the summer, while nirK abundance was enhanced from the fall to late spring. Additionally, the availability of dissolved inorganic nitrogen nutrients had no commensurable effect on $\mathrm{N}$-cycle functional genes. This study of the annual variation of $\mathrm{N}$ cycle functional genes in a temperate Atlantic estuary provides a major contribution to the understanding of how environmental factors potentially influence the distribution and abundance of $\mathrm{N}$ cycle microbial communities.
\end{abstract}

KEY WORDS: Nitrogen cycle · Environmental factors · Denitrifier · Ammonia-oxidizing Archaea · AOA $\cdot$ Ammonia-oxidizing Bacteria $\cdot$ AOB $\cdot$ Nitrogen functional genes $\cdot$ Estuary

\section{INTRODUCTION}

Understanding how environmental factors control the abundance and distribution of microorganisms is fundamental to microbial ecology studies and to evaluating the impact on global biogeochemical cycles (Fuhrman et al. 2006, Steele et al. 2011). Estuaries are dynamic ecosystems with distinct spatial and temporal environmental variations (McLusky \& Elliot 2004) that may shape the structure of microbial communities. These transition systems receive in-

${ }^{*}$ Corresponding author: psalgado@ciimar.up.pt creased loads of nutrients, particularly nitrogen which can be transformed by microbes and promote critical biogeochemical functions, leading eventually to its removal (Damashek \& Francis 2018). Denitrification and ammonia oxidation are major microbially mediated processes that play a key role in the global nitrogen (N) cycle (Voss et al. 2013). Canonical denitrification occurs under low oxygen conditions, and is a metabolic respiratory process which consists of the dissimilatory stepwise reduction of nitrate $\left(\mathrm{NO}_{3}{ }^{-}\right)$ through nitrite $\left(\mathrm{NO}_{2}^{-}\right)$, nitric oxide $(\mathrm{NO})$, nitrous restricted. Authors and original publication must be credited. 
oxide $\left(\mathrm{N}_{2} \mathrm{O}\right)$ to dinitrogen gas $\left(\mathrm{N}_{2}\right.$; Knowles 1982, Zumft 1997). The reduction of $\mathrm{N}_{2} \mathrm{O}$ to $\mathrm{N}_{2}$ is catalyzed by a metalloenzyme encoded by the clade I type nosZ (hereinafter nosZI) gene (Pauleta et al. 2013). Denitrification represents an ecologically important process. On the one hand, it promotes the biological removal of nitrogen from natural or anthropogenic systems (Seitzinger et al. 2006), reducing the eutrophication risk. On the other hand, it can affect the global climate due to the potential emission of the greenhouse gas $\mathrm{N}_{2} \mathrm{O}$ (Philippot et al. 2011). Moreover, a newly recognized and abundant phylogenetic clade of $\mathrm{N}_{2} \mathrm{O}$ reducers, which generally have an atypical NosZ protein (encoded by the clade II type nos $Z$, hereinafter nosZII), act as effective $\mathrm{N}_{2} \mathrm{O}$ consumers (Sanford et al. 2012, Jones et al. 2013, Hallin et al. 2018).

Nitrification is an autotrophic, aerobic process in which microorganisms obtain energy by converting ammonia $\left(\mathrm{NH}_{3}\right)$ to $\mathrm{NO}_{3}{ }^{-}$(Bock \& Wagner 2013). The first oxidation step of nitrification is the transformation of $\mathrm{NH}_{3}$ into $\mathrm{NO}_{2}^{-}$(nitritation), catalyzed by ammonia monooxygenase, for which most environmental studies had originally focused on the ammonia-oxidizing Bacteria (AOB), belonging to the Betaproteobacteria (Kowalchuk \& Stephen 2001). The discovery of ammonia monooxygenase genes associated with archaeal scaffolds within marine metagenomic datasets (Venter et al. 2004) subsequently confirmed the existence of marine ammonia-oxidizing Archaea (AOA; Könneke et al. 2005), usually dominating ocean nitrification (Francis et al. 2005, Wuchter et al. 2006, Santoro et al. 2011). The last oxidation step results in the transformation of $\mathrm{NO}_{2}^{-}$to $\mathrm{NO}_{3}{ }^{-}$(nitratation), by nitrite-oxidizing bacteria, eventually supplying denitrification with the required $\mathrm{NO}_{3}{ }^{-}$. Microbial ecology molecular studies use nirS, nirK, and nosZ as marker genes of denitrifying bacteria in order to quantify the functional community in several environments (Henry et al. 2006, Kandeler et al. 2006). The bacterial and archaeal amoA, that encodes the ammonia monooxygenase- $\alpha$ subunit, serve as a proxy for the quantification of ammonia oxidizers $\left(\mathrm{AO}_{i}\right.$ Rotthauwe et al. 1997, Mincer et al. 2007).

With increasing awareness about the vital role of microbial communities to ecosystem functions, and how they may be impacted by climate change (Cavicchioli et al. 2019), the need to comprehend the feedback response of microorganisms to environmental change constitutes a fundamental quest in microbial research. In estuaries, some studies advocate that the $\mathrm{AO}$ and the denitrifying communities are strongly influenced by salinity fluctuations (Bernhard et al. 2010, Francis et al. 2013). Additionally, ammonium concentration seems to be a relevant factor for the niche separation between $\mathrm{AOB}$ and $\mathrm{AOA}$ (Urakawa et al. 2014). Nitrate can influence the selection between denitrification and dissimilatory reduction to ammonia, coupled with nitrate affinity or the availability of other elements (e.g. sulfide, $\mathrm{Fe}^{2+}$ ), that may favor nitrate ammonifiers (Brunet \& GarciaGil 1996, Kessler et al. 2018).

Since habitat-specific features of ecosystems determine the diversity and distribution of microbial communities, we hypothesized that the seasonal variability of key environmental parameters may influence the distribution of $\mathrm{N}$-cycle microbial communities in a temperate estuary. Using real-time PCR, we assessed and characterized the spatial-temporal variations of key functional genes of $\mathrm{AOB}$ and $\mathrm{AOA}$ $(a m o A)$, of denitrification (nirS, nirK, nosZI), and of the novel non-denitrifying $\mathrm{N}_{2} \mathrm{O}$ reducers (nosZII). In addition, the relationships between key environmental parameters and functional gene abundance were also assessed to determine the potential environmental drivers of the distribution of $\mathrm{N}$-cycle microbial communities.

\section{MATERIALS AND METHODS}

\subsection{Study area and water sampling}

Water samples were retrieved from the Douro River estuary (NW Portugal, Fig. 1). The Douro River drains an international watershed of $97682 \mathrm{~km}^{2}$, and the estuary is limited by a hydroelectric power dam located $21.6 \mathrm{~km}$ from the mouth (Bordalo \& Vieira 2005). Mean annual flow reaches $505 \mathrm{~m}^{3} \mathrm{~s}^{-1}$, ranging from 0 to $>13000 \mathrm{~m}^{3} \mathrm{~s}^{-1}$ during the summer and winter, respectively (Vieira \& Bordalo 2000, Azevedo et al. 2010). The water is contaminated by treated and untreated sewage disposal (Ribeiro et al. 2018). The lower, middle, and upper estuarine sectors are based on the salinity gradient, according to Vieira \& Bordalo (2000).

Monthly sampling surveys were performed for 1 yr (from July 2009 to June 2010), at low tide, at 3 sampling sites (lower, middle, and upper stretches), covering the present full length of the estuary (Fig. 1). The exact position of each sampling site was obtained by means of GPS (Magellan 600). Key physical and chemical parameters, namely temperature, salinity, $\mathrm{pH}$, oxygen saturation, and turbidity, were measured in situ, using a YSI 6920 CTD multi- 


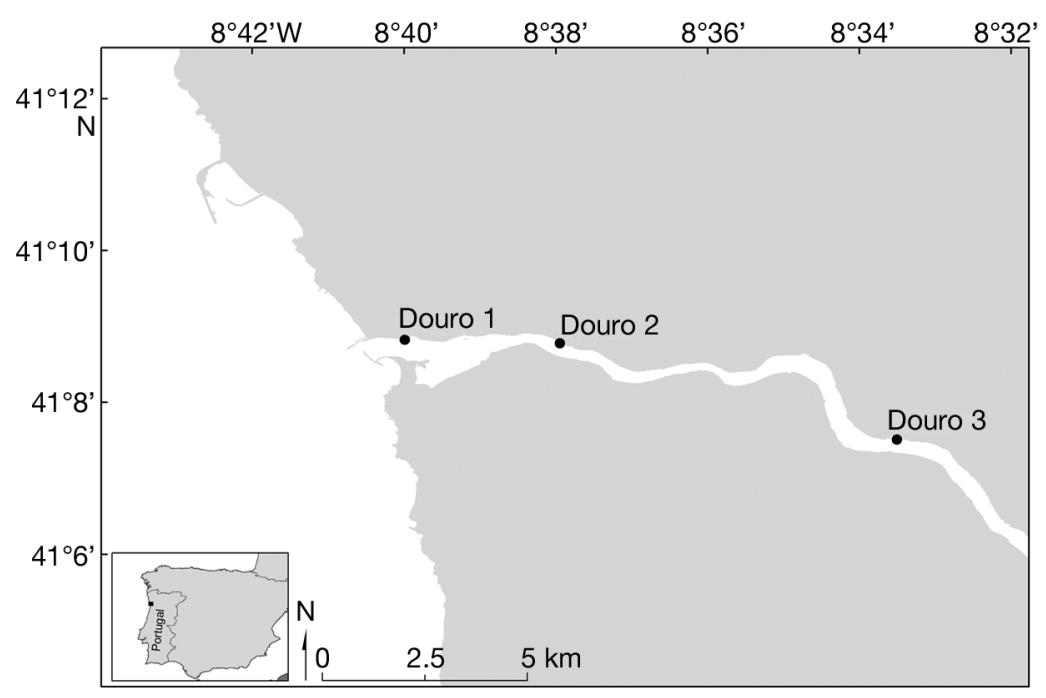

Fig. 1. Sampling sites in the Douro estuary, corresponding to the lower, middle, and upper stretches of the estuary (from west to east), according to Vieira \& Bordalo (2000)

parameter probe. Surface water samples were collected using $500 \mathrm{ml}$ acid-cleaned polyethylene bottles for chemical parameters analysis, and sterile bottles for microbiology analysis. All samples were kept in the dark, refrigerated in ice chests until further analysis.

Nutrient concentration of phosphate $\left(\mathrm{PO}_{4}{ }^{3-}\right), \mathrm{NO}_{2}{ }^{-}$, $\mathrm{NO}_{3}{ }^{-}$, and ammonium $\left(\mathrm{NH}_{4}{ }^{+}\right)$were determined colorimetrically using methods described in Grasshoff et al. (1983). Chlorophyll a (chl a) concentration was assayed according to Parsons et al. (1984). Particulate organic matter (POM) was measured as percentage of weight loss on ignition $\left(500^{\circ} \mathrm{C}, 2 \mathrm{~h}\right)$ (APHA 1992). Determination of dissolved total carbon (TC), organic carbon (DOC), and total nitrogen (TN) was performed by high-temperature catalytic oxidation with a TOC-VCSN analyzer coupled to a total nitrogenmeasuring unit (Shimadzu Instruments), according to the manufacturer's instructions.

\subsection{Nucleic acids isolation}

Water samples were concentrated onto cellulose nitrate membranes $(0.22 \mu \mathrm{m}$ pore size, $0.47 \mathrm{~mm}$ diameter, Whatman, GE Healthcare), and total DNA of each sample was extracted using the DNeasy PowerSoil Kit (QIAGEN) following the manufacturer's instructions. DNA quality was checked on $2 \%(\mathrm{w} / \mathrm{v})$ agarose gel, and quantified on a Qubit fluorometer (Life Technologies), using the Quant-iT dsDNA assay.

\subsection{Quantification of N-cycle functional genes}

All qPCR reactions were carried out in duplicate, containing 30-180 ng (for nirS, nirK, and nosZI amplification; Table S1 in the Supplement at www.int-res.com/articles/suppl/a084 p205_supp.pdf), or 5-60 ng (for nosZII and $a m o A$ from AOB and AOA amplification; Table S1) of DNA template, and Power SYBR ${ }^{\circledR}$ Green PCR Master Mix (2x), that included ROX as a passive reference, to a final $20 \mu \mathrm{l}$ reaction volume. All reactions were performed in MicroAmp Fast Optical 96-Well Reaction Plates (Bio-Rad), using optical adhesive cover, and performed on a CFX96 ${ }^{\mathrm{TM}}$ Real-Time System/C1000 ${ }^{\mathrm{TM}}$ Thermal cycler (Bio-Rad). A no-template control was included for each run. Gene-specific primer sequences and thermal cycling conditions are detailed in Table S1. A composite sample was prepared by adding equal volumes of all the extracted DNA samples from the Douro estuary. This composite sample was used as a template for the amplification of each gene, and the resulting PCR amplicon was analyzed by agarose gel electrophoresis, and subsequently quantified by fluorometry. Quantification of functional gene abundance was achieved through calibration curves for each target gene by serially diluting (10-fold) the PCR amplicon. Gene copy numbers were determined based on the calibration curves, assuming 1 gene copy per genome (except the AOB, carrying an average of 2.5 copies), and normalized against the mass (ng) of the extracted DNA. To evaluate qPCR reaction specificity, a melting curve analysis was performed at the end of each reaction, and all PCR products were analyzed on $2 \%(\mathrm{w} / \mathrm{v})$ agarose gel to ensure that only the expected target genes were amplified without artifacts. qPCR results were analyzed with the software Bio-Rad CFX Manager 1.6.

\subsection{Data analysis}

Statistical analysis was performed with the opensource software R, version 3.3.3 (R Development Core Team 2013). The proportion of N-cycle functional genes and total microbial community was estimated by normalizations against the RNA polymerase subunit gene $(r p o B$; Dahllöf et al. 2000, Vos et 
al. 2012). Significant changes in the ratios and abundance of each functional gene were analyzed by means of the Mann-Whitney $U$-test ( $p<0.001)$, after examining the distribution and homoscedasticity of the data using the Shapiro-Wilk and Levene tests, respectively (Levene 1960, Shapiro \& Wilk 1965). For the ordination analysis, non-normally distributed data were $\log$ transformed. Temporal associations between the environmental parameters and the $\mathrm{N}$ cycle functional genes were analyzed with the standardized data (to zero mean and unit variance), through a constrained redundancy analysis (RDA) performed with the vegan package (Oksanen et al. 2018). Collinearity between environmental variables was evaluated using the variance inflation factor (VIF). Collinear variables with a VIF > 10 were excluded from the RDA model. General associations between environmental parameters and functional gene abundances were further explored with the Spearman's rank correlation coefficient, with the correlation p-values calculated by means of the corrplot and Hmisc packages (Wei \& Simko 2016, Harrell 2019).

\section{RESULTS}

\subsection{Environmental characterization}

Temperature ranged from lower values in the winter months $\left(8.0-10.9^{\circ} \mathrm{C}\right)$, to higher values in the summer $\left(21-24.7^{\circ} \mathrm{C}\right.$, Fig. 2a). Salinity decreased from November to May (0.1-4.8), due to higher river runoff (Fig. S1 in the Supplement), while September displayed the highest salinity, in the range 13.9-29.5 (Fig. 2b). The lowest dissolved oxygen (DO) concentrations were observed in July $(2.0 \mathrm{mg}$ $\mathrm{l}^{-1}$, lower estuary), while higher oxygenation was found during the winter season $\left(10.8-15.0 \mathrm{mg} \mathrm{l}^{-1}\right.$, Fig. 2c). Phytoplankton chl a peaked in July $(9.8 \mu \mathrm{g}$ $\mathrm{l}^{-1}$, upper estuary), and August $\left(10.1 \mathrm{\mu g} \mathrm{l}^{-1}\right.$, lower estuary), corresponding to the summer phytoplankton bloom (Fig. 2d). During the winter months, turbidity increased, namely in January at the lower estuary (33.5 NTU), and in March at the upper stretch (33.2 NTU, Fig. 2e). TN ranged from 0.017 to $3.21 \mathrm{mg} \mathrm{l}^{-1}$ (Fig. 2f), with overall higher concentrations in the winter, while POM levels fluctuated during the sampling surveys (Fig. 2g). The annual distribution of ammonium and nitrite concentrations ranged from 0.8 to $134.8 \mu \mathrm{M}$ (Fig. $2 \mathrm{~h}$ ), and from 0.2 to $2.8 \mu \mathrm{M}$ (Fig. 2i), respectively, with a peak in September in the upper estuary. Nitrate was the most abundant inorganic nitrogen form (24.6-373.1 $\mu \mathrm{M}$, Fig. 2j), with the highest concentrations observed in August in the lower stretch.

\subsection{Relationships between environmental variables and functional genes}

The Douro estuary presented environmental gradients associated with seasonality, a characteristic of temperate ecosystems. After selecting the studied environmental variables, we used a subset of the matrix for the constrained RDA in order to determine which environmental variables best correlated with the variance of $\mathrm{N}$-cycle functional genes. As a result, the entire microbial community variation could be explained by the environmental variables $(90.1 \%$, Fig. 3), which significantly $\left(R^{2}=0.507 ; p<0.05 ; 999\right.$ permutations) influenced the $\mathrm{N}$-cycle functional genes. Overall, all $\mathrm{N}$-cycle functional genes in the Douro estuary were abundant in well-oxygenated waters, being negatively influenced by temperature and salinity. In particular, nirS, nirK, and bacterial and archaeal amoA presented higher abundances in the fall and winter months when temperature and salinity were lowest (Fig. 2), and displayed significant correlations with DO ( $p<0.01$, Fig. 4, Table S2 in the Supplement). TN was significantly linked to the abundance of nosZII and nirK ( $\mathrm{p}<0.05)$, and nirS and nosZI ( $p<0.01$, Fig. 4, Table S2). Curiously, both AO were not associated with the availability of ammonium, typically the substrate used by ammonia oxidizers. Instead, AO were more related to turbidity, which was the explanatory variable most strongly related with the first RDA axis (Fig. 3). Turbidity in the estuary was strongly linked to DO $(\mathrm{p}<0.001$, Figs. $3 \& 4$ ). As expected, the seasonal profiles of turbidity and river flow were similar, with an increase during winter and spring (Fig. 2e, Fig. S1). In addition, linear regression analysis suggested that $37-$ $47 \%$ of the variability in nirS, nirK, and archaeal amoA abundance (Fig. S2 in the Supplement) was significantly explained by river flow $(\mathrm{p}<0.05)$.

The RDA showed that archaeal and bacterial amoA and nirS were mostly associated with the winter and spring seasons, also evidenced by the temporal profiles of the functional gene abundances which were clearly enhanced in those seasons (see Fig. 5), when the water was well oxygenated and murky. Additionally, nirS was significantly correlated with all functional genes $(p<0.001)$, mainly with the bacterial amoA, which was also demonstrated by the similar spatial-temporal gene abundance patterns (Fig. 3). 

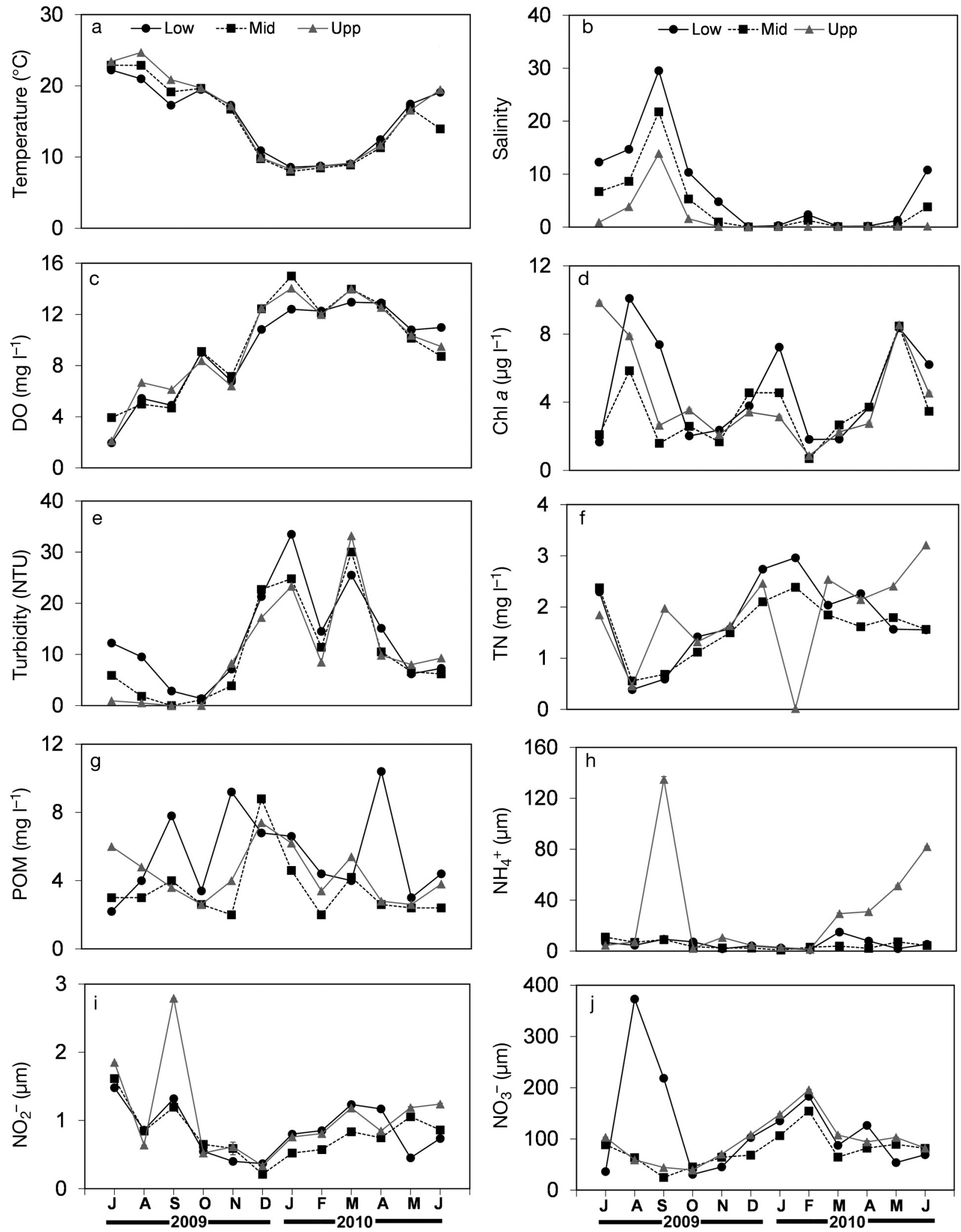

Fig. 2. Seasonal variability of (a) temperature, (b) salinity, (c) dissolved oxygen (DO), (d) chl $a_{1}$ (e) turbidity, (f) total nitrogen (TN), (g) particulate organic matter (POM), (h) $\mathrm{NH}_{4}{ }^{+}$, (i) $\mathrm{NO}_{2}{ }^{-}$, and (j) $\mathrm{NO}_{3}{ }^{-}$(mean $\pm \mathrm{SD}, 3$ replicates; small SDs are hidden behind symbols), in the lower (low), middle (mid), and upper (upp) stretches of the Douro river estuary, from July 2009 to June 2010 


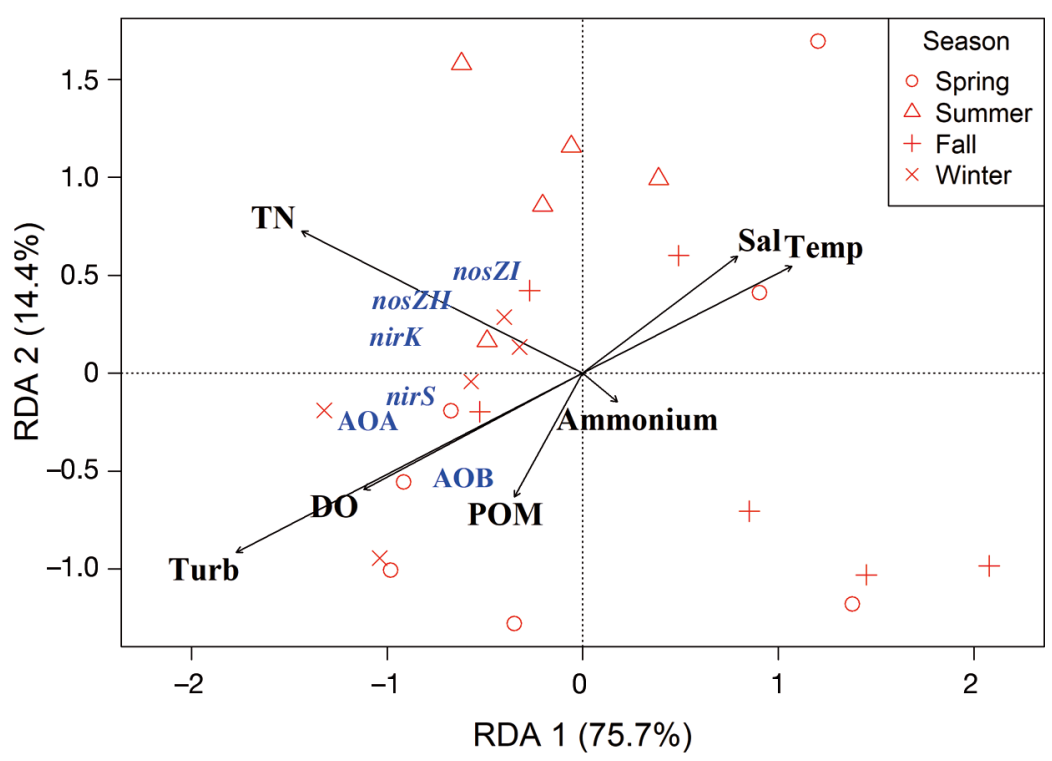

Fig. 3. Ordination triplot of redundancy analysis (RDA) between physicalchemical parameters and seasonal distributions of ammonia oxidizers (bacterial [AOB] and archaeal [AOA] amoA genes), denitrifying (nirS, nirK, nosZI), and non-denitrifying (nosZII) functional gene abundance, in the Douro estuary. Each ordination axis represents the proportion of variance explained by environmental variables. DO: dissolved oxygen; POM: particulate organic matter; Sal: salinity; Temp: temperature; TN: total nitrogen; Turb: turbidity

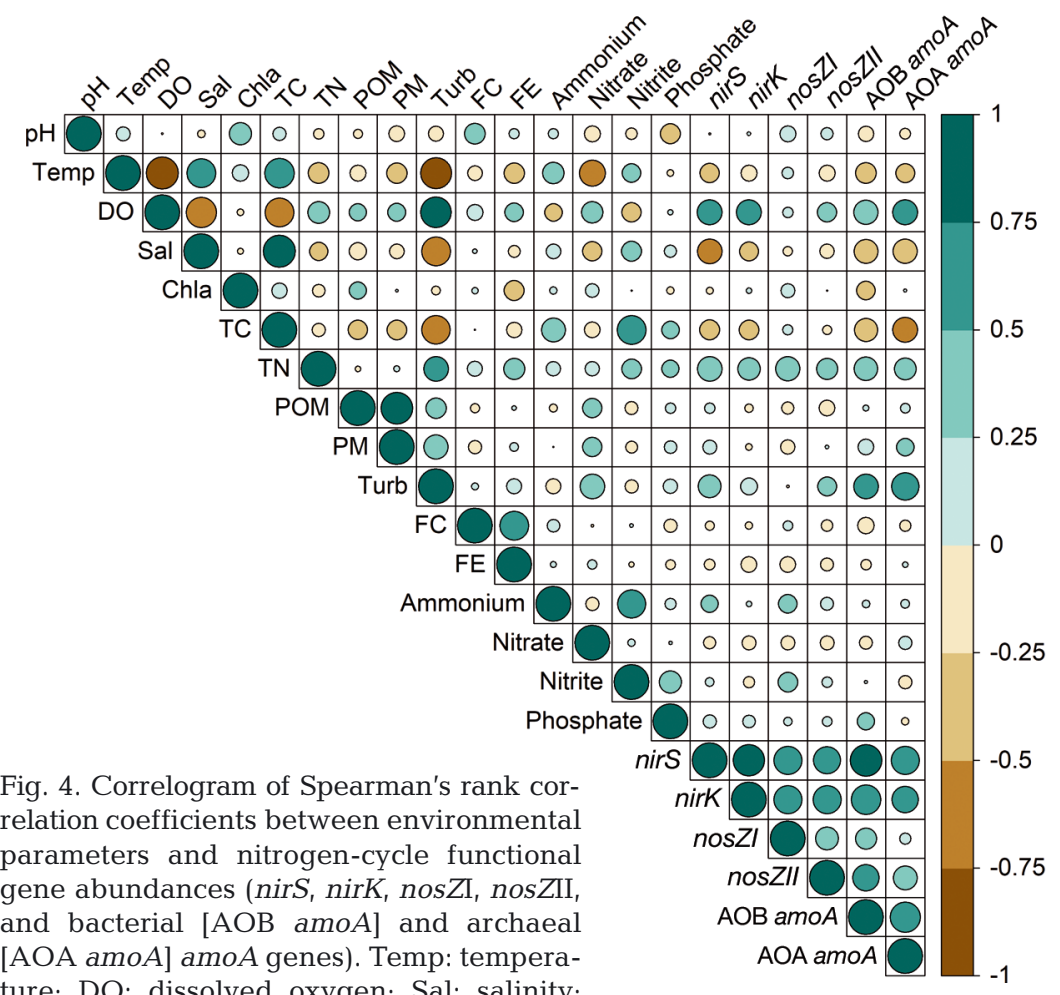

ture; DO: dissolved oxygen; Sal: salinity;

TC: total carbon; TN: total nitrogen; POM: particulate organic matter; PM: particulate matter; Turb: turbidity; FC: fecal coliform;

FE: fecal enterococci
The bacterial community (based on rpoB gene abundance) revealed a different temporal profile, with higher values occurring mainly in the fall (Fig. S3 in the Supplement). On the other hand, the proportion of the bacterial $\mathrm{N}$-cycle functional genes in ratio to $r p o B$ gene abundance yielded a significant seasonal variability $(\mathrm{p}<0.01$; Fig. S4 in the Supplement) in the 3 sections of the estuary. The highest ratio was observed in August, occurring at the same time as the highest chl a concentration (Fig. 2d).

\subsection{Distribution of $\mathbf{N}$-cycle functional genes}

Overall, the results displayed distinct patterns of $\mathrm{N}$-cycle functional gene abundance (Fig. 5). Archaeal amoA peaked in mid-summer (July) in the middle estuary, to recover again during the winter months (Fig. 5a). Bacterial amoA abundance also increased during late winter (FebruaryMarch), at the upper and lower stretches of the estuary, while the middle estuary showed a lower abundance $\left(2.6 \times 10^{6}\right.$ gene copies $\mathrm{ng}^{-1}$ DNA, Fig. 5b). The denitrifying communities had different temporal distributions throughout the year. For instance, nirK-type denitrifiers' abundance varied from $4.4 \times 10^{5}$ to $3.0 \times 10^{7}$ gene copies ng $^{-1}$ DNA (Fig. 5c), with higher concentrations in early fall (October) within the estuary, decreasing towards late winter (February). The abundance of nirS was higher upstream in mid-fall (November), expanding throughout the estuary during winter (Fig. 5d). The nosZII abundance, related to the non-denitrifying $\mathrm{N}_{2} \mathrm{O}$ reducers, increased during the winter period (December-March), particularly in the middle estuary (Fig. 5e). The nosZI denitrifying communities remained low throughout the year $\left(1.1 \times 10^{5}\right.$ to $3.7 \times 10^{6}$ gene copies $\mathrm{ng}^{-1}$ DNA), with a seasonal profile different from nirS and nirK increased 

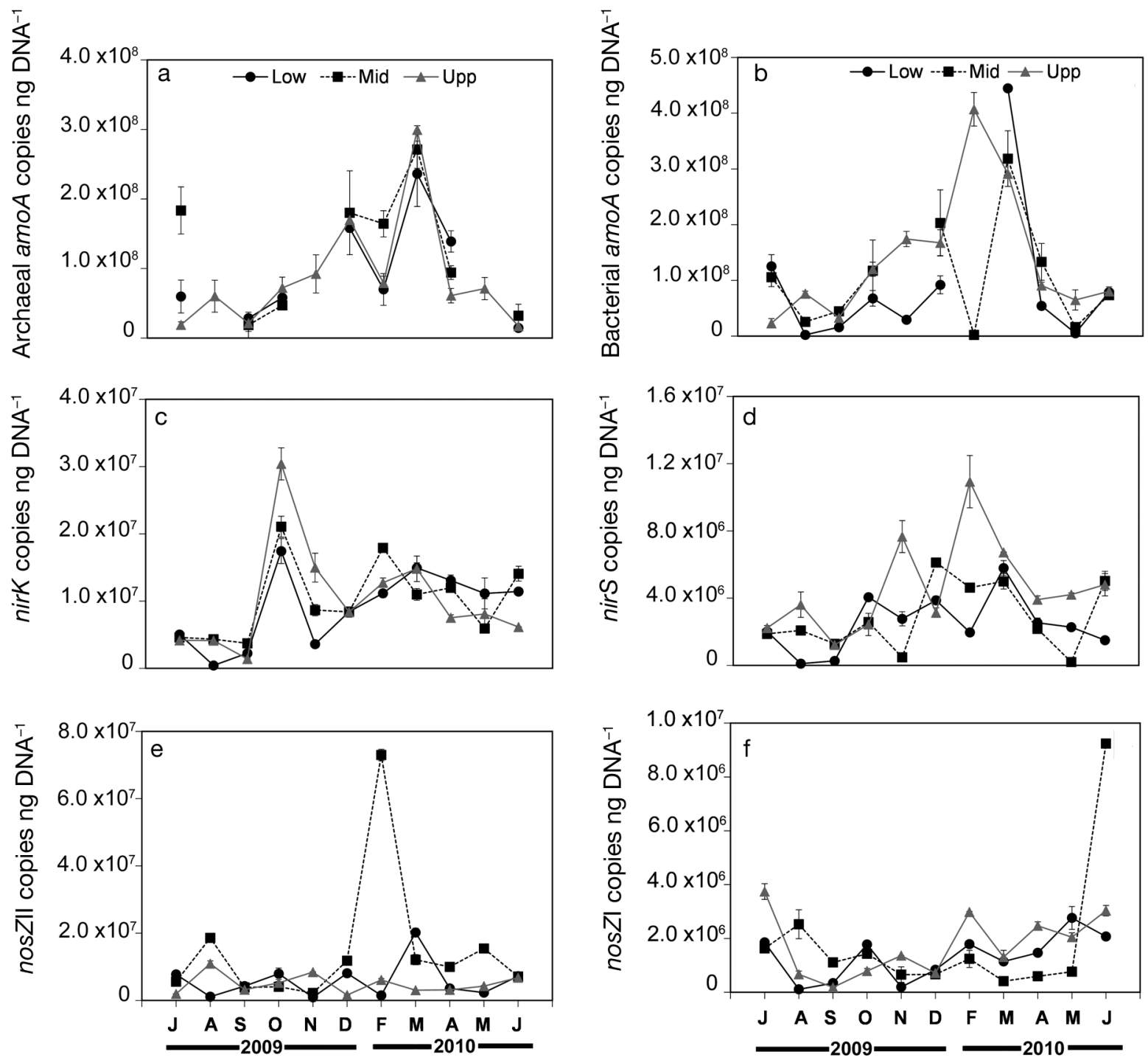

Fig. 5. Spatial-temporal distribution of (a) archaeal amoA, (b) bacterial amoA, (c) nirK, (d) nirS, (e) nosZII, and (f) nosZI, in water samples from the lower (low), middle (mid), and upper (upp) stretches of the Douro estuary, from July 2009 to June 2010. Relative abundance of each functional gene expressed as gene copies normalized to ng of extracted DNA. Error bars: SD of the mean. Samples from January 2010 were missing, and that month was not included in the analysis

abundance was observed at the onset of the summer (June), within the middle estuary (Fig. 5f).

\section{DISCUSSION}

In the Douro estuary, the microbial N-cycle gene abundances had distinct seasonal patterns, constrained by environmental factors. All studied N-cycle functional genes were generally more abundant in welloxygenated, lower-temperature and -salinity waters, typical of the winter season. Therefore, the distribution of denitrifying nirS, nirK, nosZII, and bacterial and archaeal amoA was influenced by the seasonal- ity of the environmental factors. Previous studies (Santoro et al. 2006, Jones \& Hallin 2010, Francis et al. 2013) have demonstrated that the diversity and abundance of denitrifying communities can be governed by environmental variables, responding differently to estuarine salinity and temperature gradients. Likewise, Lee \& Francis (2017) observed in San Francisco Bay that nirK had a higher relative abundance with low temperatures, while nirS was enhanced with high nitrate concentrations. But in the Douro estuary, nirS had higher gene abundance mainly during the winter season, with low temperature and salinity, highlighting the specificities of different estuaries. The denitrifying enzymes NirK or NirS 
(encoded by the nirK and nirS genes, respectively) are structurally different and believed to be nonhomologous, responding differently to environmental gradients (Jones \& Hallin 2010). Additionally, the distribution of the denitrifying nosZI and non-denitrifying nosZII genes was predominantly related to DO, an important environmental factor that leads to niche partitioning between nosZ clades I and II, as demonstrated by Wittorf et al. (2016). Nevertheless, all studied $\mathrm{N}$-cycle genes, including the denitrifying ones, were abundant in highly oxygenated estuarine waters. Although denitrification and $\mathrm{N}_{2} \mathrm{O}$ reduction are anaerobic processes, the occurrence of these functional genes in well-oxygenated waters can be derived from the presence of microorganisms that possess both nitrifying and denitrifying genes.

The present study evaluated the microbial community by DNA analysis, but the presence of functional genes does not necessarily indicate the presence of the expected activities. However, certain organisms can possess and express denitrification genes under aerobic growth, i.e. the activity is stimulated when organisms face a switch between anoxic to oxic conditions (Ka et al. 1997, Morley et al. 2008, Marchant et al. 2017). On the other hand, denitrification can occur in the presence of low levels of oxygen when microorganisms are metabolizing in anoxic microenvironments, such as within suspended particles (reviewed by Brezonik 2013). Estuaries are dynamic bodies of water that receive freshwater inputs resulting in high inorganic nutrient and phytoplankton fluxes, stimulating primary production (Joint \& Pomroy 1981). Additionally, the freshwater runoff delivers dissolved and particulate materials that foster turbidity in the estuary. Indeed, in the Douro estuary, turbidity played a major role in the distribution of denitrifying nirS, the non-denitrifying $\mathrm{N}_{2} \mathrm{O}$ reducers (nosZII), and the AO, which may be an indication of particle-attached microorganisms that are also capable of ammonia oxidation (Jing et al. 2018, Cai et al. 2019). Indeed, the occurrence of denitrification activity has been associated to small and large particles in coastal, river, and estuarine waters (Michotey \& Bonin 1997, Liu et al. 2013). The existence of anoxic microenvironments inside suspended or sinking particles, associated with high turbidity, is evidence of hotspots for POM remineralization and a niche for the occurrence of the heterotrophic denitrification process in the water column (Simon et al. 2014, Bianchi et al. 2018, Zhu et al. 2018). Still, since denitrifiers are also capable of aerobic respiration, the presence of denitrifying genes is not necessarily an indication of denitrification activity.
The Douro estuary is highly dynamic, influenced by the river flow (Vieira \& Bordalo 2000). The increased abundance of archaeal and bacterial amoA in the winter season (December-March) was strongly associated with turbidity when the river flow peaks. Indeed, high nitrification rates have been observed in turbid estuarine waters, with strong correlations with suspended particulate matter, possibly influenced by resuspension of benthic nitrifiers or abiotic ammonium release from sediment (Damashek et al. 2016, Sanders \& Laanbroek 2018). On the other hand, the higher turbidity in the lower estuary may also be related to sewage discharge, associated with increased levels of ammonium and fecal indicators (Azevedo et al. 2006, 2008). However, the abundance of the fecal indicators and the levels of ammonium were not correlated with any of the studied N-cycle functional genes, suggesting that sewage does not seem to be a relevant source for those genes in the Douro estuary. Additionally, river flow can act to transport biogenic matter and shape the estuarine community, as well as influence the physical-chemical characteristics of estuaries, changing the environmental conditions (de Oliveira \& Margis 2015, Fortunato \& Crump 2015, Smith et al. 2019). Although river runoff in the Douro estuary statistically explains the variability of the nirS, nirK, and archaeal amo $A$ abundances, river flow fails to show significant $(\mathrm{p}>0.05)$ relationships with the abundance of $\mathrm{N}$-cycle genes. Therefore, its importance is not evident for explaining the spatial-temporal dynamics of the abovementioned functional genes. During the freshet in the winter season, residence time in the water column decreases (Vieira \& Bordalo 2000). Consequently, during that period, the river runoff continuously exports microbial populations towards nearshore and/or until they reach a 'hotspot' with extended water retention which gives enough time to increase the relative growth rate (Crump et al. 2004).

Ammonia oxidation kinetics can influence the niche separation between AOB and AOA (MartensHabbena et al. 2009). Surprisingly, in the Douro estuary, archaeal and bacterial amoA were not correlated with ammonium. Although $\mathrm{AO}$ are known to use $\mathrm{NH}_{3}$ rather than $\mathrm{NH}_{4}{ }^{+}$as a substrate for their chemotrophic growth (Suzuki 1974), the presence of ammonium in the water column, independent of its origin, is indicative of a nitrification potential (Sanders \& Laanbroek 2018). The high inorganic nutrient loads may not be limiting the nitrifying and denitrifying activity, which may explain the absence of correlation to $\mathrm{N}$-cycle 
functional genes. Environmental parameters other than ammonium did influence the AO abundances. Both AOB and AOA may exhibit a wide adaptive range of tolerance to environmental gradients and adapt to different estuarine characteristics (Bernhard et al. 2007, Gao et al. 2018). Salinity gradients have been associated with changes in the community structure and nitrification activity, but without consistent results for AO community shifts and distribution patterns (de Bie et al. 2001, Bernhard et al. 2005, 2007, Santoro et al. 2008). Although Magalhães et al. (2009) observed that the abundance of AOB in sandy sediments of the Douro estuary dominated over AOA, and positively correlated with salinity, the present study found a different pattern in the water column. Indeed, the AO abundance was more associated with low-temperature and low-salinity waters, as well as with high concentrations of DO and high levels of turbidity, usually occurring during the winter months.

Although the normalization against total DNA is a quantification approach used in molecular studies to measure the potential for $\mathrm{N}$-cycle processes in the ecosystem (e.g. Christman et al. 2011, Wakelin et al. 2011, Soper et al. 2018), it is possible that on a temporal and spatial scale, changes in non-bacterial DNA contents could have biased the results. Additionally, because ecological data, especially from estuarine studies, are complex and explanatory variables are often correlated among each other (multicollinearity), caution must be exercised when interpreting results and making inferences. The co-occurrence between the functional genes can potentially represent an interaction between microorganisms, which reflects the influence of the environment on their distribution (Faust \& Raes 2012, Graf et al. 2014). In the present study, the strong relationship between nirS and bacterial and archaeal amoA indicated that these genes can be correlated with the same environmental variables. Nevertheless, the similar spatialtemporal distribution pattern between these genes, and the association with turbidity, may also suggest the potential coupling between nitrification and denitrification processes, namely for particle-associated assemblages (Zhang et al. 2014, 2019, Zhu et al. 2018). AO can remineralize the available organic matter while fueling the oxidation of the reduced inorganic nitrogenous compounds to nitrite/nitrate, making it available for denitrifiers to reduce (Zhu et al. 2013). Surprisingly, a noticeable association between nirK abundance and the nosZII group was observed. Denitrifying organisms that harbor nirK instead of nirS are likely to have a truncated denitrification lacking the last step of $\mathrm{N}_{2} \mathrm{O}$ reduction (Graf et al. 2014). This link can hypothetically represent the interaction of microorganisms that perform single or isolated steps of each denitrification process, working as a co-op community through metabolic handoffs, and the final product of one organism is the substrate of the other (Hug \& Co 2018). This cooperation represents an interesting topic to be further explored, since there is a growing awareness of the interactions between organisms and how these networks shape and link biogeochemical cycles (Anantharaman et al. 2016).

\section{CONCLUSIONS}

Few studies have addressed how N-cycle processes and microbial communities respond to environmental change in the water column. Our research contributes to an improved understanding of how the microbial communities involved in the $\mathrm{N}$-cycle are influenced by environmental factors in the waters of an estuarine system, and the potential implications on the microbial structure and N-biogeochemical cycle. The Douro river estuary was found to have a specific environmental fingerprint that influenced the distribution and abundance of $\mathrm{N}$-functional genes, with potential biogeochemical feedbacks. Overall, temperature, salinity, turbidity, and DO exerted a stronger influence on the variability of the genes encoding nitrite reductase (nirS and nirK), the nondenitrifying nosZII, and bacterial and archaeal ammonia monooxygenase- $\alpha$ subunit (amoA). To some extent, the environmental patterns benefited the relationships between the N-cycle functional genes. Therefore, the obtained results support the assumption that the combination of habitat-specific environmental variables, and not an isolated factor, may shape the structure of microbial communities, and control their abundance and distribution. Overall, the present study provides insight into the potential dynamics of $\mathrm{N}$-cycle microbial communities responding to environmental change in a temperate estuary, and into the regulation of the newly recognized marine nondenitrifying $\mathrm{N}_{2} \mathrm{O}$ reducers.

Acknowledgements. Our team thanks Jacinto Cunha for the cartography and advice on statistical analysis. P.S. acknowledges financial support from the Portuguese Foundation for Science and Technology (FCT), through a PhD fellowship (SFRH/BD/105659/2015) co-financed by POPH/FSE. This study was also partially supported by the project UNNOWN (PTDC/BTA-BTA/31098/2017), co-financed by COMPETE 2020, Portugal 2020, and the European Union through the ERDF, and by FCT through national funds. 


\section{LITERATURE CITED}

Anantharaman K, Brown CT, Hug LA, Sharon I and others (2016) Thousands of microbial genomes shed light on interconnected biogeochemical processes in an aquifer system. Nat Commun 7:13219

APHA (1992) Standard methods for examination of wastewater, 14th edn. APHA, New York, NY

Azevedo IC, Duarte PM, Bordalo AA (2006) Pelagic metabolism of the Douro estuary (Portugal) - factors controlling primary production. Estuar Coast Shelf Sci 69:133-146

Azevedo IC, Duarte PM, Bordalo AA (2008) Understanding spatial and temporal dynamics of key environmental characteristics in a mesotidal Atlantic estuary (Douro, NW Portugal). Estuar Coast Shelf Sci 76:620-633

Azevedo IC, Bordalo AA, Duarte PM (2010) Influence of river discharge patterns on the hydrodynamics and potential contaminant dispersion in the Douro estuary (Portugal). Water Res 44:3133-3146

Bernhard AE, Donn T, Giblin AE, Stahl DA (2005) Loss of diversity of ammonia-oxidizing bacteria correlates with increasing salinity in an estuary system. Environ Microbiol 7:1289-1297

Bernhard AE, Tucker J, Giblin AE, Stahl DA (2007) Functionally distinct communities of ammonia-oxidizing bacteria along an estuarine salinity gradient. Environ Microbiol 9:1439-1447

Bernhard AE, Landry ZC, Blevins A, de la Torre JR, Giblin AE, Stahl DA (2010) Abundance of ammonia-oxidizing Archaea and Bacteria along an estuarine salinity gradient in relation to potential nitrification rates. Appl Environ Microbiol 76:1285-1289

Bianchi D, Weber TS, Kiko R, Deutsch C (2018) Global niche of marine anaerobic metabolisms expanded by particle microenvironments. Nat Geosci 11:263-268

Bock E, Wagner M (2013) Oxidation of inorganic nitrogen compounds as an energy source. In: Rosenberg E, DeLong EF, Lory S, Stackebrandt E, Thompson F (eds) The prokaryotes: prokaryotic physiology and biochemistry. Springer, Berlin, p 83-118

Bordalo AA, Vieira MEC (2005) Spatial variability of phytoplankton, bacteria and viruses in the mesotidal salt wedge Douro Estuary (Portugal). Estuar Coast Shelf Sci 63:143-154

Brezonik PL (2013) Denitrification in natural waters. In: Jenkins SH (ed) Proceedings of the Conference on Nitrogen as a Water Pollutant. Pergamon, Oxford, p 373-392

Brunet RC, Garcia-Gil LJ (1996) Sulfide-induced dissimilatory nitrate reduction to ammonia in anaerobic freshwater sediments. FEMS Microbiol Ecol 21:131-138

Cai X, Yao L, Hu Y, Jiang H and others (2019) Particle-attached microorganism oxidation of ammonia in a hypereutrophic urban river. J Basic Microbiol 59:511-524

Cavicchioli R, Ripple WJ, Timmis KN, Azam F and others (2019) Scientists' warning to humanity: microorganisms and climate change. Nat Rev Microbiol 17:569-586

Christman GD, Cottrell MT, Popp BN, Gier E, Kirchman DL (2011) Abundance, diversity, and activity of ammonia-oxidizing prokaryotes in the coastal Arctic Ocean in summer and winter. Appl Environ Microbiol 77: 2026-2034

Crump BC, Hopkinson CS, Sogin ML, Hobbie JE (2004) Microbial biogeography along an estuarine salinity gradient: combined influences of bacterial growth and residence time. Appl Environ Microbiol 70:1494-1505
Dahllöf I, Baillie H, Kjelleberg S (2000) rpoB-based microbial community analysis avoids limitations inherent in 16S rRNA gene intraspecies heterogeneity. Appl Environ Microbiol 66:3376-3380

* Damashek J, Francis CA (2018) Microbial nitrogen cycling in estuaries: from genes to ecosystem processes. Estuar Coasts 41:626-660

Wamashek J, Casciotti KL, Francis CA (2016) Variable nitrification rates across environmental gradients in turbid, nutrient-rich estuary waters of San Francisco Bay. Estuar Coasts 39:1050-1071

* de Bie MJM, Speksnijder AGCL, Kowalchuk GA, Schuurman $T$ and others (2001) Shifts in the dominant populations of ammonia-oxidizing $\beta$-subclass Proteobacteria along the eutrophic Schelde estuary. Aquat Microb Ecol 23:225-236

* de Oliveira LFV, Margis R (2015) The source of the river as a nursery for microbial diversity. PLOS ONE 10:e0120608

Faust K, Raes J (2012) Microbial interactions: from networks to models. Nat Rev Microbiol 10:538-550

Fortunato CS, Crump BC (2015) Microbial gene abundance and expression patterns across a river to ocean salinity gradient. PLOS ONE 10:e0140578

Francis CA, Roberts KJ, Beman JM, Santoro AE, Oakley BB (2005) Ubiquity and diversity of ammonia-oxidizing archaea in water columns and sediments of the ocean. Proc Natl Acad Sci USA 102:14683-14688

* Francis C, O'Mullan G, Cornwell J, Ward B (2013) Transitions in nirS-type denitrifier diversity, community composition, and biogeochemical activity along the Chesapeake Bay estuary. Front Microbiol 4:237

Fuhrman JA, Hewson I, Schwalbach MS, Steele JA, Brown MV, Naeem S (2006) Annually reoccurring bacterial communities are predictable from ocean conditions. Proc Natl Acad Sci USA 103:13104-13109

*Gao J, Hou L, Zheng Y, Liu M, Yin G, Yu C, Gao D (2018) Shifts in the community dynamics and activity of ammonia-oxidizing prokaryotes along the Yangtze estuarine salinity gradient. J Geophys Res Biogeosci 123:34583469

Garaf DRH, Jones CM, Hallin S (2014) Intergenomic comparisons highlight modularity of the denitrification pathway and underpin the importance of community structure for $\mathrm{N}_{2} \mathrm{O}$ emissions. PLOS ONE 9:e114118

Grasshoff K, Ehrhardt M, Kremling K (1983) Methods of seawater analysis, 2nd edn. Verlag Chemie, Weinheim

* Hallin S, Philippot L, Löffler FE, Sanford RA, Jones CM (2018) Genomics and ecology of novel $\mathrm{N}_{2} \mathrm{O}$-reducing microorganisms. Trends Microbiol 26:43-55

Harrell FE (2019) Hmisc: Harrell miscellaneous. R package version 4.3-0. https://CRAN.R-project.org/package=Hmisc

*Henry S, Bru D, Stres B, Hallet S, Philippot L (2006) Quantitative detection of the nos $Z$ gene, encoding nitrous oxide reductase, and comparison of the abundances of $16 \mathrm{~S}$ rRNA, narG, nirK, and nosZ genes in soils. Appl Environ Microbiol 72:5181-5189

Hug LA, Co R (2018) It takes a village: Microbial communities thrive through interactions and metabolic handoffs. mSystems 3:e00152-17

* Jing H, Zhu W, Liu H, Zheng L, Zhang Y (2018) Particleattached and free-living archaeal communities in the benthic boundary layer of the Mariana Trench. Front Microbiol 9:2821

Joint IR, Pomroy AJ (1981) Primary production in a turbid estuary. Estuar Coast Shelf Sci 13:303-316 
Jones CM, Hallin S (2010) Ecological and evolutionary factors underlying global and local assembly of denitrifier communities. ISME J 4:633-641

Jones CM, Graf DRH, Bru D, Philippot L, Hallin S (2013) The unaccounted yet abundant nitrous oxide-reducing microbial community: a potential nitrous oxide sink. ISME J 7: $417-426$

Ka JO, Urbance J, Ye RW, Ahn TY, Tiedje JM (1997) Diversity of oxygen and $\mathrm{N}$-oxide regulation of nitrite reductases in denitrifying bacteria. FEMS Microbiol Lett 156: $55-60$

Kandeler E, Deiglmayr K, Tscherko D, Bru D, Philippot L (2006) Abundance of narG, nirS, nirK, and nosZ genes of denitrifying bacteria during primary successions of a glacier foreland. Appl Environ Microbiol 72:5957-5962

Kessler AJ, Roberts KL, Bissett A, Cook PLM (2018) Biogeochemical controls on the relative importance of denitrification and dissimilatory nitrate reduction to ammonium in estuaries. Global Biogeochem Cycles 32:1045-1057

Knowles R (1982) Denitrification. Microbiol Rev 46:43-70

Könneke M, Bernhard AE, de la Torre JR, Walker CB, Waterbury JB, Stahl DA (2005) Isolation of an autotrophic ammonia-oxidizing marine archaeon. Nature 437:543-546

Kowalchuk GA, Stephen JR (2001) Ammonia-oxidizing bacteria: a model for molecular microbial ecology. Annu Rev Microbiol 55:485-529

* Lee JA, Francis CA (2017) Spatiotemporal characterization of San Francisco Bay denitrifying communities: a comparison of nirK and nirS diversity and abundance. Microb Ecol 73:271-284

Levene H (1960) Robust tests for equality of variances. In: Olkin I, Ghurye SG, Hoeffding W, Madow WG, Mann HB (eds) Contributions to probability and statistic: essays in honor of Harold Hotelling. Stanford University Press, Palo Alto, p 278-292

Liu T, Xia X, Liu S, Mou X, Qiu Y (2013) Acceleration of denitrification in turbid rivers due to denitrification occurring on suspended sediment in oxic waters. Environ Sci Technol 47:4053-4061

*Magalhães CM, Machado A, Bordalo AA (2009) Temporal variability in the abundance of ammonia-oxidizing bacteria vs. archaea in sandy sediments of the Douro River estuary, Portugal. Aquat Microb Ecol 56:13-23

Marchant HK, Ahmerkamp S, Lavik G, Tegetmeyer HE and others (2017) Denitrifying community in coastal sediments performs aerobic and anaerobic respiration simultaneously. ISME J 11:1799-1812

Martens-Habbena W, Berube PM, Urakawa H, de la Torre JR, Stahl DA (2009) Ammonia oxidation kinetics determine niche separation of nitrifying Archaea and Bacteria. Nature 461:976-979

McLusky DS, Elliott M (2004) The estuarine ecosystem: ecology, threats and management. Oxford University Press, Oxford

Michotey V, Bonin P (1997) Evidence for anaerobic bacterial processes in the water column: denitrification and dissimilatory nitrate ammonification in the northwestern Mediterranean Sea. Mar Ecol Prog Ser 160:47-56

Mincer TJ, Church MJ, Taylor LT, Preston C, Karl DM, DeLong EF (2007) Quantitative distribution of presumptive archaeal and bacterial nitrifiers in Monterey Bay and the North Pacific Subtropical Gyre. Environ Microbiol 9: 1162-1175

Morley N, Baggs EM, Dörsch P, Bakken L (2008) Production of $\mathrm{NO}, \mathrm{N}_{2} \mathrm{O}$ and $\mathrm{N}_{2}$ by extracted soil bacteria, regulation by $\mathrm{NO}_{2}{ }^{-}$and $\mathrm{O}_{2}$ concentrations. FEMS Microbiol Ecol 65: $102-112$

Oksanen J, Guillaume F, Friendly M, Kindt R and others (2018) vegan: community ecology package. R package version 2.5-1. https://CRAN.R-project.org/package=vegan

Parsons TR, Maita Y, Lalli CM (1984) A manual of chemical and biological methods for seawater analysis. Pergamon Press, Oxford

*Pauleta SR, Dell'Acqua S, Moura I (2013) Nitrous oxide reductase. Coord Chem Rev 257:332-349

* Philippot L, Andert J, Jones CM, Bru D, Hallin S (2011) Importance of denitrifiers lacking the genes encoding the nitrous oxide reductase for $\mathrm{N}_{2} \mathrm{O}$ emissions from soil. Glob Change Biol 17:1497-1504

R Development Core Team (2013) R: a language and environment for statistical computing. R Foundation for Statistical Computing. Vienna. www.R-project.org

Kibeiro C, Couto C, Ribeiro AR, Maia AS and others (2018) Distribution and environmental assessment of trace elements contamination of water, sediments and flora from Douro River estuary, Portugal. Sci Total Environ 639: 1381-1393

Rotthauwe JH, Witzel KP, Liesack W (1997) The ammonia monooxygenase structural gene $a m o A$ as a functional marker: molecular fine-scale analysis of natural ammonia-oxidizing populations. Appl Environ Microbiol 63: 4704-4712

Sanders T, Laanbroek HJ (2018) The distribution of sediment and water column nitrification potential in the hyper-turbid Ems estuary. Aquat Sci 80:33

Sanford RA, Wagner DD, Wu Q, Chee-Sanford JC and others (2012) Unexpected nondenitrifier nitrous oxide reductase gene diversity and abundance in soils. Proc Natl Acad Sci USA 109:19709-19714

* Santoro AE, Boehm AB, Francis CA (2006) Denitrifier community composition along a nitrate and salinity gradient in a coastal aquifer. Appl Environ Microbiol 72:2102-2109

* Santoro AE, Francis CA, De Sieyes NR, Boehm AB (2008) Shifts in the relative abundance of ammonia-oxidizing bacteria and archaea across physicochemical gradients in a subterranean estuary. Environ Microbiol 10:1068-1079

* Santoro AE, Buchwald C, Mcllvin MR, Casciotti KL (2011) Isotopic signature of $\mathrm{N}_{2} \mathrm{O}$ produced by marine ammoniaoxidizing archaea. Science 333:1282-1285

* Seitzinger S, Harrison JA, Böhlke JK, Bouwman AF and others (2006) Denitrification across landscapes and waterscapes: a synthesis. Ecol Appl 16:2064-2090

Shapiro SS, Wilk MB (1965) An analysis of variance test for normality (complete samples). Biometrika 52:591-611

* Simon HM, Smith MW, Herfort L (2014) Metagenomic insights into particles and their associated microbiota in a coastal margin ecosystem. Front Microbiol 5:466

* Smith MW, Herfort L, Rivers AR, Simon HM (2019) Genomic signatures for sedimentary microbial utilization of phytoplankton detritus in a fast-flowing estuary. Front Microbiol 10:2475

* Soper FM, Sullivan BW, Nasto MK, Osborne BB and others (2018) Remotely sensed canopy nitrogen correlates with nitrous oxide emissions in a lowland tropical rainforest. Ecology 99:2080-2089

Steele JA, Countway PD, Xia L, Vigil PD and others (2011) Marine bacterial, archaeal and protistan association networks reveal ecological linkages. ISME J 5:1414-1425

Suzuki I (1974) Mechanisms of inorganic oxidation and energy coupling. Annu Rev Microbiol 28:85-102 
Urakawa H, Martens-Habbena W, Huguet C, de la Torre JR, Ingalls AE, Devol AH, Stahl DA (2014) Ammonia availability shapes the seasonal distribution and activity of archaeal and bacterial ammonia oxidizers in the Puget Sound Estuary. Limnol Oceanogr 59:1321-1335

Venter JC, Remington K, Heidelberg JF, Halpern AL and others (2004) Environmental genome shotgun sequencing of the Sargasso Sea. Science 304:66-74

Vieira MEC, Bordalo AA (2000) The Douro estuary (Portugal): a mesotidal salt wedge. Oceanol Acta 23:585-594

Vos M, Quince C, Pijl AS, de Hollander M, Kowalchuk GA (2012) A comparison of $r p o B$ and 16S rRNA as markers in pyrosequencing studies of bacterial diversity. PLOS ONE 7:e30600

Voss M, Bange HW, Dippner JW, Middelburg JJ, Montoya JP, Ward B (2013) The marine nitrogen cycle: recent discoveries, uncertainties and the potential relevance of climate change. Philos Trans R Soc B 368:20130121

Wakelin SA, Nelson PN, Armour JD, Rasiah V, Colloff MJ (2011) Bacterial community structure and denitrifier (nirgene) abundance in soil water and groundwater beneath agricultural land in tropical North Queensland, Australia. Soil Res 49:65-76

Wei T, Simko V (2016) corrplot: visualization of a correlation matrix. R package version 0.77 . https://CRAN.R-project. org/package $=$ corrplot

Editorial responsibility: Ilana Berman-Frank, Haifa, Israel
Wittorf L, Bonilla-Rosso G, Jones CM, Bäckman O, Hulth S, Hallin S (2016) Habitat partitioning of marine benthic denitrifier communities in response to oxygen availability. Environ Microbiol Rep 8:486-492

*Wuchter C, Abbas B, Coolen MJL, Herfort L and others (2006) Archaeal nitrification in the ocean. Proc Natl Acad Sci USA 103:12317-12322

Khang Y, Xie X, Jiao N, Hsiao SSY, Kao SJ (2014) Diversity and distribution of amoA-type nitrifying and nirS-type denitrifying microbial communities in the Yangtze River estuary. Biogeosciences 11:2131-2145

* Zhang Y, Song C, Zhou Z, Cao X, Zhou Y (2019) Coupling between nitrification and denitrification as well as its effect on phosphorus release in sediments of Chinese shallow lakes. Water 11:1809

* Zhu X, Burger M, Doane TA, Horwath WR (2013) Ammonia oxidation pathways and nitrifier denitrification are significant sources of $\mathrm{N}_{2} \mathrm{O}$ and $\mathrm{NO}$ under low oxygen availability. Proc Natl Acad Sci USA 110: 6328-6333

Zhu W, Wang C, Hill J, He Y, Tao B, Mao Z, Wu W (2018) A missing link in the estuarine nitrogen cycle?: Coupled nitrification-denitrification mediated by suspended particulate matter. Sci Rep 8:2282

Zumft WG (1997) Cell biology and molecular basis of denitrification. Microbiol Mol Biol Rev 61:533-616

Submitted: August 22, 2019; Accepted: April 28, 2020 Proofs received from author(s): June 25, 2020 